\title{
Genetic Variability, Heritability and Genetic Advance for Yield Traits in Tomato (Solanum lycopersicum L.)
}

\author{
H.R. Bhandari ${ }^{1 *}$, Kartikeya Srivastava ${ }^{2}$ and G. Eswar Reddy ${ }^{2}$ \\ ${ }^{1}$ Scientist, ICAR-Central Seed Research Station for Jute and Allied Fibres, BudBud, \\ Burdwan, West Bengal, PIN-7137403, India \\ ${ }^{2}$ Department of Genetics \& Plant Breeding, Institute of Agricultural Sciences, \\ Banaras Hindu University, Varanasi, Uttar Pradesh, PIN-21005, India \\ *Corresponding author
}

\section{A B S T R A C T}

The genetic parameters of variability were studied for ten yield traits in 66

Keywords

Tomato,

Solanum

lycopersicum.

Article Info

Accepted:

29 June 2017

Available Online:

10 July 2017 genotypes of tomato. Highly significant genotypic differences were reported for all the traits. The maximum coefficient of range was reported for average fruit weight followed by fruit yield $(\mathrm{Kg}) /$ plant, number of seeds/fruit and total number of fruits/plant. The maximum estimate of phenotypic and genotypic variance was recorded for number of seeds/fruit followed by plant height, average fruit weight and total number of fruits/plant. The trait fruit yield $(\mathrm{Kg}) / \mathrm{plant}$ recorded the maximum heritability followed by number of fruits/cluster. Important yield traits namely average fruit weight, number of fruits/plant, number of seeds/fruit and fruit yield $(\mathrm{Kg}) / \mathrm{plant}$ revealed high heritability coupled with high Genetic Advance as percentage of mean. Simple selection or pure line selection following hybridization may be effective for improvement in yield traits.

\section{Introduction}

Tomato is one of the major vegetable crops cultivated throughout the world. It ranks $2^{\text {nd }}$ among vegetable crops and $7^{\text {th }}$ in the list of important crop species worldwide. In India, it is next only to potato and onion among vegetables in terms of production. Since its introduction in $16^{\text {th }}$ century, it has spread to almost all the parts of the world and is being grown commercially in 159 countries (Saker et al., 2011). The crop has become popular among farmers because of its short duration, high yield potential, high profitability and economic viability. On account of its high nutritive (Ram, 2005) and protective values
(Chauhan et al., 2014), it is one of the most consumed vegetables in different forms. It is highly valued in processing industries for its peculiar sensorial properties.

Tomato is a diploid species with 12 pairs of chromosomes. It is a member of solanaceae family and is close to several other important crops like brinjal, chilly, potato, tobacco. It has its primary center of diversity in a narrow belt along the Andean region of Ecuador and Peru (Carelli et al., 2006). It was domesticated in $16^{\text {th }}$ century and its consumption started in the later part of $18^{\text {th }}$ 
century. Within short span of time, it has gained the major share of vegetable production across the world.

Tomato accounts for $15 \%$ of world vegetable production (FAO, 2013). China, India, USA, Turkey, Egypt, Iran, Italy, Brazil, Spain etc. are the major producers of tomato. India is the $2^{\text {nd }}$ largest producer of tomato in terms of both area and production. In India, it is cultivated over an area of nearly $0.80 \mathrm{mha}$ (DAC, 2016). Madhya Pradesh, Andhra Pradesh, Karnataka, Odisha are the major producing states of tomato in India. It has the share of nearly $8.3 \%$ of total vegetable area and $10.3 \%$ of total vegetable production in India. Though, Tomato is one of the major vegetables exported from India, per capita consumption in India is abysmally low (Srivastava et al., 2016). In the year 2014-15, an estimated $0.22 \mathrm{mt}$ of tomato worth 44 461.34 Lakh were exported from India.

Being an important vegetable crop, yield improvement is one of the major breeding objectives particularly in Indian context as the average Indian yield levels (21.2 t/ha) are far below the world average of $33.9 \mathrm{t} / \mathrm{ha}$ (National Horticulture Board, 2014). Being a complex trait, yield improvement is dependent on improvement in other traits contributing yield. Hence, the information on genetics of yield and yield traits is essential. Yield improvement of any crop is subject to formulation of efficient breeding programmes. Deployment of a particular breeding strategy needs an insight into the components of genetic variability. Genetic variability is estimated by phenotypic and genotypic coefficient of variation. Heritability estimates are indicative of transmissibility of a particular trait. This also gives an indication of environmental influences in the expression of a particular trait. Genetic advance refers to improvement of the selected progenies over the base population. The information on heritability in conjunction with genetic advance is needed for effective selection (Johnson et al., 1955).

Many studies on genetic variability are available in tomato (Saeed et al., 2007; Khanom et al., 2008; Shashikanth et al., 2010; Reddy et al., 2013; Nwosu et al., 2014). Most of these studies involved very small number of test genotypes. For a confirmative study, it is desirable to estimate the components of genetic variability using more number of test genotypes covering wide geographical distribution. Furthermore, it is essential to confirm the previous results using new accessions and at other locations. In this context, the present investigation was carried out to unravel the components of genetic variability, heritability and genetic advance of important yield traits in 66 genotypes tomato representing released varieties, improved lines, local collection and germplasm from India and abroad.

\section{Materials and Methods}

\section{Experimental site and Environment}

The present investigation was carried out at Vegetable Farm, Institute of Agricultural Sciences, Banaras Hindu University, Varanasi. The experimental site is located in the middle Ganges valley in the Eastern part of the state of Uttar Pradesh at $25^{\circ} 19^{\prime} 59^{\prime \prime} \mathrm{N}$ latitude, and longitude: $83^{\circ} 00^{\prime} 00^{\prime \prime} \mathrm{E}$ longitude and at elevation of $77 \mathrm{~m}$ above mean sea level. The climate of the location is characterized as humid subtropical climate with large variations between summer and winter temperatures. The average annual rainfall is $1,110 \mathrm{~mm}$ (44 in). Fog is common in the winters, while hot dry winds, blow in the summer.

\section{Experimental material, Experimentation and observation}

The experimental material comprised of 66 genotypes of tomato collected from different 
institutes and agricultural universities across India and abroad and maintained at Department of Genetics and Plant Breeding, Institute of Agricultural Sciences, Banaras Hindu University, Varanasi. The test genotypes are listed in table 1.

The nursery was raised in $2^{\text {nd }}$ fortnight of August-2014. Due care was taken to get the healthy seedlings. The 25-day-old crop was transplanted in the main field. The experiment was laid out in Randomized Complete Block design (RCBD) with three replications. An inter-row spacing of $60 \mathrm{~cm}$ and inter-plant distance of $45 \mathrm{~cm}$ was maintained. All the recommended package of practices was followed to get a healthy crop. Data were recorded from five randomly selected plants for ten yield traits viz., days to 50\% flowering, plant height, number of primary branches per plant, number of flowers/cluster, number of fruits/cluster, number of fruits per plant average fruit weight, number of locules/fruit, number of seeds/fruit and yield/plant.

\section{Statistical Analyses}

Analysis of variance was done based on RCBD as suggested by Panse and Sukhatme (1985) for each of the characters separately. The total variation was split into variation due to replication, genotypes and error. The phenotypic and genotypic coefficient of variance was estimated according to Burton and De Vane (1953). The heritability in broad sense and genetic advance was calculated as per Johnson et al., (1955). Coefficient of range was calculated using following formula:

Coef ficient of range $=\frac{H-L}{H+L}$

Where,

$\mathrm{H}$ is the highest value in a set of observation and

$\mathrm{L}$ is the lowest value in a set of observation.

\section{Results and Discussion}

The analysis of variance revealed highly significant differences among genotypes for all the traits indicating presence of considerable variability for the traits under study among the test genotypes (Table 3 ).

The different genetic parameters like range, mean, phenotypic coefficient of variation, genotypic coefficient of variation, heritability, genetic advance and genetic advance as a percentage of mean are presented in table 2 .

The range was the maximum for number of seeds/fruit (172.7) followed by number of fruits/plant (92.5), average fruit weight (71.8) and plant height (58.8). This is in agreement with reports of Golani et al., (2007) who reported wide variability for average fruit weight, fruit yield( $\mathrm{Kg})$ /plant, and plant height. Patel et al., (2013) also reported higher range for average fruit weight in tomato. Meena et al., (2015) also reported high estimates of range for fruit yield/ plant and plant height. The range is not a very robust measure of dispersion.

Hence, coefficient of range (a relative measure of dispersion) was calculated as it is a more precise estimate of variability.

The maximum coefficient of range was reported for average fruit weight (0.97) followed by fruit yield(Kg) /plant (0.94), number of seed/fruit (0.73) and total number of fruits/plant (0.66) indicating existence of sufficient variability among the test genotypes for the traits. The least coefficient of range was noted for days to $50 \%$ flowering. The existing wide variability can be efficiently employed in direct selection for improved plant type as a short term strategy.

The data indicated that phenotypic variance was greater than genotypic variance for all the 
traits under study. The maximum estimate of phenotypic and genotypic variance, respectively was recorded for number of seeds/fruit (770.30 and 721.94) followed by plant height (186.59 and 160.11), average fruit weight (181.12 and 176.89) and total number of fruits/plant (174.58 and 170.11).

The least estimate of phenotypic and genotypic variance was recorded for fruit yield(Kg) /plant (0.28 and 0.27). Mohamed et al., (2012) also reported higher estimates of genotypic variance for plant height and average fruit weight. Meena and Bahahdur (2014) also recorded high estimates of phenotypic and genotypic variance for plant height. Narrow difference between the estimates of phenotypic and genotypic variance indicated higher contribution of genetic component towards total variability.

Accordingly, phenotypic coefficient of variance was greater than genotypic coefficient of variance for all the traits. The narrow difference between phenotypic coefficient of variation and genotypic coefficient of variation was indicative of lesser influence of environment on expression of these traits.

Similar findings were reported by Khapte and Jansirani (2014), Patel et al., (2013) and Golani et al., (2007). The difference between phenotypic and genotypic coefficient of variance was comparatively larger for number of locules/fruit and days to $50 \%$ flowering. Heritability in broad sense estimate ranged from 80.02 to $98.92 \%$.

The trait fruit yield $(\mathrm{Kg}) /$ plant recorded the maximum heritability $(98.92 \%)$ followed by number of fruits/cluster (98.69\%). All the traits with the exception of days to $50 \%$ flowering and number of locules/fruit recorded heritability of more than $90 \%$. Days to $50 \%$ flowering and number of locules/fruit recorded heritability of 80.02 and $88.68 \%$, respectively. This is in agreement with the reports of Nwosu et al., (2014) and Reddy et al., (2013) who reported higher estimates of heritability for important yield traits like fruit weight, number of fruits/cluster etc.

Genetic advance as a per cent of mean (GAM) ranged from 15.91 to 71.93 . The least GAM was observed for days to $50 \%$ flowering (15.91) followed by plant height (32.14), number of flowers/cluster (36.38) and number of primary branches/plant (37.44). Moderate GAM (<60) was observed for number of fruits/cluster (40.29) and number of locules/fruit (42.26).

High estimates of GAM (>60) was observed for average fruit weight (62.88), number of seeds/fruit (70.23), fruit yield( $\mathrm{Kg})$ /plant (70.68) and number of fruits/plant (71.93). Khapte and Jansirani (2014) also reported low GAM for plant height and number of primary branches/plant and high GAM for fruit yield(Kg)/plant.

Present study indicated that phenotypic selection may be fruitful for the traits showing higher GAM viz., average fruit weight, number of fruits/plant number of seeds/fruit and fruit yield(Kg)/plant.

GAM must be considered in conjunction with heritability. Important yield traits namely average fruit weight, number of fruits/plant, number of seeds/fruit and fruit yield $(\mathrm{Kg})$ /plant revealed high heritability coupled with high GAM. This indicated the additive gene effect in determination of these traits. Comparatively low heritability coupled with low GAM for days to $50 \%$ flowering revealed the influence of environment on the trait. 
Table.1 List of genotypes included in genetic variability study

\begin{tabular}{|c|c|c|c|c|c|}
\hline S. No. & Genotype & Source/Origin & S. No. & Genotype & Source/Origin \\
\hline 1 & EC 620578 & IIVR, Varanasi & 34 & EC 538423 & IIVR, Varanasi \\
\hline 2 & EC 521087 & IIVR, Varanasi & 35 & Punjab Upma & PAU, Ludhiana \\
\hline 3 & EC 520061 & IIVR, Varanasi & 36 & Kajela & - \\
\hline 4 & EC 20510 & IIVR, Varanasi & 37 & DT-2 & IIVR, Varanasi \\
\hline 5 & EC 620541 & IIVR, Varanasi & 38 & DVRT1-2 & IIVR, Varanasi \\
\hline 6 & EC 531803 & IIVR, Varanasi & 39 & DT-10 & IARI, New Delhi \\
\hline 7 & Nandi & IIHR, Bangalore & 40 & HT-4 & - \\
\hline 8 & EC 528374 & IIVR, Varanasi & 41 & TLC-1 & - \\
\hline 9 & EC 538156 & IIVR, Varanasi & 42 & T- Local & Tripura \\
\hline 10 & EC 620530 & IIVR, Varanasi & 43 & Selection-7 & HAU, Hissar \\
\hline 11 & Kashi Sharad & IIVR, Varanasi & 44 & NDT-3 & NDUA\&T, Faizabad \\
\hline 12 & EC 620536 & IIVR, Varanasi & 45 & NDTVR-60 & NDUA\&T, Faizabad \\
\hline 13 & EC 538411 & IIVR, Varanasi & 46 & VR-20 & - \\
\hline 14 & EC 620538 & IIVR, Varanasi & 47 & Angurlata & - \\
\hline 15 & EC 605694 & IIVR, Varanasi & 48 & Azad T-5 & CSUA\&T, Kanpur \\
\hline 16 & CLN 2116 & AVRDC, Taiwan & 49 & Flawery & USA \\
\hline 17 & EC 538434 & IIVR, Varanasi & 50 & Superbug & USA \\
\hline 18 & EC 538380 & IIVR, Varanasi & 51 & GT & Gujarat \\
\hline 19 & EC 620419 & IIVR, Varanasi & 52 & FLA 7171 & USA \\
\hline 20 & EC 168283 & IIVR, Varanasi & 53 & Co-3 & TNAU, Coimbatore \\
\hline 21 & EC 538155 & IIVR, Varanasi & 54 & Arka Vikas & IIHR, Bangalore \\
\hline 22 & EC 521069 & IIVR, Varanasi & 55 & Kashi Amrit & IIVR, Varanasi \\
\hline 23 & EC 620438 & IIVR, Varanasi & 56 & NDT 8 & NDUA\&T, Faizabad \\
\hline 24 & BS-24-2 & - & 57 & PM-1 & IARI, New Delhi \\
\hline 25 & EC 538440 & - & 58 & H-88-78-1 & IIVR, Varanasi \\
\hline 26 & PS-1 & IARI, New Delhi & 59 & Swarna Naveen & - \\
\hline 27 & BS-31-3 & - & 60 & Floradel & Florida, USA \\
\hline 28 & BS-18-7 & - & 61 & Feb-04 & - \\
\hline 29 & Columbia & USA & 62 & Kashi Anupam & IIVR, Varanasi \\
\hline 30 & B-S-2-5 & - & 63 & Pusa Sadabahar & - \\
\hline 31 & Pant-T-3 & GBPUA\&T & 64 & Shalimar-2 & - \\
\hline 32 & $\mathrm{H}-24$ & - & 65 & BT-120 & -- \\
\hline 33 & Kashi Vshesh & IIVR, Varanasi & 66 & NDTVR-73 & NDUA\&T, Faizabad \\
\hline
\end{tabular}


Table. 2 Genetic parameters of different yield traits

\begin{tabular}{|l|c|l|c|c|c|c|c|c|c|c|}
\hline $\begin{array}{l}\text { Parameter/ } \\
\text { Trait }\end{array}$ & $\begin{array}{l}\text { General } \\
\text { Mean }\end{array}$ & Range & $\begin{array}{l}\text { Coefficient } \\
\text { of range }\end{array}$ & PV & GV & PCV & GCV & h' (bs) & $\begin{array}{l}\text { Genetic } \\
\text { Advance }\end{array}$ & $\begin{array}{l}\text { Genetic } \\
\text { Advance as \% } \\
\text { of mean }\end{array}$ \\
\hline DF (50\%) & 44.78 & $35.3-55.7$ & 0.22 & 29.15 & 18.67 & 12.06 & 9.65 & 80.02 & 7.12 & 15.91 \\
\hline $\begin{array}{l}\text { Plant Height } \\
\text { (cm) }\end{array}$ & 75.12 & $46.2-105.0$ & 0.39 & 186.59 & 160.11 & 18.18 & 16.85 & 92.68 & 24.15 & 32.14 \\
\hline $\begin{array}{l}\text { No of primary } \\
\text { branches }\end{array}$ & 4.52 & $2.0-6.7$ & 0.54 & 0.91 & 0.78 & 21.07 & 19.57 & 92.88 & 1.69 & 37.44 \\
\hline $\begin{array}{l}\text { No of } \\
\text { flowers/cluster }\end{array}$ & 5.23 & $3.5-8.7$ & 0.43 & 1.05 & 0.95 & 19.59 & 18.60 & 94.95 & 1.90 & 36.38 \\
\hline $\begin{array}{l}\text { No of } \\
\text { fruits/cluster }\end{array}$ & 4.26 & $2.5-6.7$ & 0.46 & 0.99 & 0.83 & 23.32 & 21.36 & 91.60 & 1.71 & 40.29 \\
\hline $\begin{array}{l}\text { Total no of } \\
\text { fruits/plant }\end{array}$ & 36.87 & $23.5-116.0$ & 0.66 & 174.58 & 170.11 & 35.84 & 35.37 & 98.69 & 26.52 & 71.93 \\
\hline $\begin{array}{l}\text { Average fruit } \\
\text { weight (g) }\end{array}$ & 43.06 & $1.2-73.0$ & 0.97 & 181.12 & 176.89 & 31.25 & 30.89 & 98.85 & 27.08 & 62.88 \\
\hline $\begin{array}{l}\text { No of } \\
\text { seeds/fruit }\end{array}$ & 76.30 & $32.0-204.7$ & 0.73 & 770.30 & 721.94 & 36.38 & 35.22 & 96.81 & 53.58 & 70.23 \\
\hline $\begin{array}{l}\text { No of } \\
\text { locules/fruit }\end{array}$ & 3.21 & $1.8-5.6$ & 0.51 & 0.70 & 0.55 & 26.07 & 23.12 & 88.68 & 1.35 & 42.26 \\
\hline $\begin{array}{l}\text { Fruit yield } \\
\text { (Kg/ha) }\end{array}$ & 1.51 & $0.1-3.2$ & 0.94 & 0.28 & 0.27 & 35.07 & 34.69 & 98.92 & 1.07 & 70.68 \\
\hline
\end{tabular}


Table.3 Analysis of variance for different economic traits

\begin{tabular}{|l|l|l|l|l|l|}
\hline Trait/ Source of variation & $\begin{array}{l}\text { Replication } \\
\text { MSS }\end{array}$ & $\begin{array}{l}\text { Genotype } \\
\text { MSS }\end{array}$ & $\begin{array}{l}\text { Error } \\
\text { MSS }\end{array}$ & CV & $\begin{array}{l}\text { SE } \\
(\mathbf{d}) \pm\end{array}$ \\
\hline Degree of freedom & 2 & 65 & 130 & - & - \\
\hline DF (50\%) & $38.87 *$ & $66.49 * * *$ & 10.48 & 7.23 & 2.64 \\
\hline Plant Height & 6.1 & $506.8 * * *$ & 26.48 & 6.85 & 4.20 \\
\hline No of primary branches & $0.74 * *$ & $2.47 * * *$ & 0.12 & 7.81 & 0.29 \\
\hline No of flowers/ cluster & 0.12 & $2.94 * * *$ & 0.10 & 6.15 & 0.26 \\
\hline No of fruits/ cluster & 0.18 & $2.64 * * *$ & 0.16 & 9.37 & 0.33 \\
\hline Total no of fruits/ plant & 11.97 & $514.79 * * *$ & 4.47 & 5.74 & 1.73 \\
\hline Average fruit weight & 0.28 & $534.91 * * *$ & 4.23 & 4.78 & 1.68 \\
\hline No of seeds/ fruit & 131.17 & $2214.18^{* * *}$ & 48.37 & 9.12 & 5.68 \\
\hline No of locules/ fruit & 0.13 & $1.80 * * *$ & 0.15 & 12.03 & 0.32 \\
\hline Fruit yield/ ha & 0.02 & $0.83 * * *$ & 0.01 & 5.17 & 0.06 \\
\hline
\end{tabular}

MSS: Mean sum of squares; CV: Coefficient of variation; SE(d): Standard Error of difference; *: Significant at 5\% probability; **: Significant at $1 \%$ level of probability; ***: Significant at $0.1 \%$ level of probability

This trait can be improved by hybridization. The study revealed that simple selection or pure line selection following hybridization in early generations may be rewarding for improvement in improvement of important yield traits.

\section{References}

Burton, G.W., and De vane, E.H. 1953. Estimating heritability in tall fenscue (Festeca arundina ceae) from replicated clonal material. Agron. J., 45: 478-481.

Carelli, B.P., Gerald, L.T.S., Grazziotin, F.G., and Echeverrigaray, S. 2006. Genetic diversity among Brazilian cultivars and landraces of tomato Lycopersicon esculentum Mill. revealed by RAPD markers. Genetic Res. Crop Evol., 53: 395-400.

Chauhan, V.B.S., Rajkumar, Behera, T.K. and Yadav, R.K.. 2014. Studies on heterosis for yield and its attributing traits in tomato (Lycopersicum esculentum L.), Int. J. Agric. Environ. and Biotech., 7(1): 95-100.

DAC. 2016. Ministry of Agriculture \&
Farmers Welfare, Government of India, Horticultural Statistics at a Glance 2015, Oxford University Press, New Delhi, India. 437pp.

FAO. 2013. FAOSTAT Database. Rome, Italy.

Golani, I.J., Mehta, D.R., Purohit, V.L., Pandya, H.M., and Kanzariya, M.V. 2007. Genetic variability, correlation and path coefficient studies in tomato. Indian J. Agric. Res., 41(2): 146 - 149, 2007

Johnson, H.W., Robinson, H.F., and Comstock, R.E. 1955. Estimates of genetic and environmental variability in soybean. Agron. J., 47: 314-318.

Khanom, M.S.R., Khan, M.H.K., and Hassan, L. 2008. Variability, heritability and genetic advance for yield and yield contributing characters in Tomato (Lycopersicon esculentum Mill.). Progress. Agric., 19(1): 1-5.

Khapte, P.S. and Jansirani, P. 2014. Genetic Variability and Performance Studies of Tomato (Solanum lycopersicum L.) Genotypes for Fruit Quality and Yield. Trends in Biosci., 7(12): 1246-1248. 
Meena, O.P., and Bahadur, Vijay. 2014. Assessment of genetic variability, heritability and genetic advance among tomato (Solanum lycopersicum 1.) germplasm. The Bioscan, 9(4): 16191623.

Meena, O.P., Bahadur, V., Jagtap, A.B., Saini, P. and Meena, Y.K. 2015. Genetic variability studies of fruit yield and its traits among indeterminate tomato genotypes under open field condition. African J. Agri. Res., 10(32): 3170-3177.

Mohamed, S.M., Ali, E.E., Mohamed, T.Y. 2012. Study of Heritability and Genetic Variability among Different Plant and Fruit Characters of Tomato (Solanum lycopersicon L.). Int. J. Scientific \& Technol. Res., 1(2): 55-58.

National Horticulture Board. 2014. Indian Horticulture database 2014, Gurgaon, India.

Nwosu, D.J., Onakoya, O.A., Okere, A.U., Babatunde, A.O., and Popoola, A.F. 2014. Genetic variability and correlations in rainfed Tomato (Solanum spps.) accessions in Ibadan, Nigeria. Greener J. Agri. Sci., 4(5): 211-219.

Panse, V.G. and Sukhatme, P.V. 1985. Statistical methods for agricultural workers, $\left(3^{\text {rd }}\right.$ Ed.) ICAR, New Delhi, India.

Patel, S.A., Kshirsagar, D.B., Attar, A.V., and Bhalekar, M.N. 2013. Study on genetic variability, heritability and genetic advance in tomato. Int. J. Plant Sci.,
8(1): 45-47.

Ram, H.H. 2005. Vegetable breedingPrinciples and practices. Kalyani Publishers, New Delhi, India. 514 pp.

Reddy B. Rajasekhar, Reddy, D. Siddeswar, Reddaiah, K. and Sunil, N. 2013. Studies on genetic variability, heritability and genetic advance for yield and quality traits in Tomato (Solanum lycopersicum L.). Int. J. Curr. Microbiol. App. Sci., 2(9): 238-244.

Saeed Asif, Hayat Kheizer, Khan Asif Ali, Iqbal Sajid and Abbas Ghulam. 2007. Assessment of Genetic Variability and Heritability in Lycopersicon esculentum Mill. Int. J. Agri. \& Biol., 9(2): 375377.

Saker, M.M., Salama, H.S., Salama, M., ElBanna, A. and Abdel Ghany, N.M. 2011. Production of transgenic tomato plants expressing Cry $2 \mathrm{Ab}$ gene for the control of some lepidopterous insects endemic in Egypt. J. Genetic Engi. Biotech., 9: 149-155.

Shashikanth, Basavaraj, N., Hosamani, R.M., and Patil, B.C. 2010. Genetic variability in tomato (Solanum lycopersicon [Mill].Wettsd.). Karnataka J. Agric. Sci., 23(3): 536-537.

Srivastava, Kartikeya, Kumar Sunil, Bhandari, H.R. and Vaishampayan, A. 2016. Search for tomato hybrids suited for high temperature stress condition. Proceedings of SABRAO 13th Congress and International Conference, Bogor, Indonesia, 137150.

\section{How to cite this article:}

Bhandari, H.R., Kartikeya Srivastava and Eswar Reddy, G. 2017. Genetic Variability, Heritability and Genetic Advance for Yield Traits in Tomato (Solanum lycopersicum L.). Int.J.Curr.Microbiol.App.Sci. 6(7): 4131-4138. doi: https://doi.org/10.20546/ijcmas.2017.607.428 